few; no toxic effects have been observed beyond some sense of malaise and fatigue for a day or two after administration. It is given by deep intramuscular injection, and this sometimes gives rise to pain at the site of injection. It is injected at fortnightly intervals in a solution of $1 \mathrm{gr}$. (65 mg.). in $1 \mathrm{ml}$., the dose to begin with being $0.5 \mathrm{ml}$; this may be increased up to $1 \mathrm{ml}$. and the interval then may be a month; after six or eight doses an interval of a few months is desirable.

\section{Pressure Cooking}

Q. -When food is cooked at $20 \mathrm{lb}$. $(9 \mathrm{~kg}$.) positive pressure, and at a temperature up to $250^{\circ} \mathrm{F}$. $\left(121^{\circ} \mathrm{C}\right.$.), is there any loss of food value compared with ordinary cooking, and does it incur a greater risk of food-poisoning, especially from meat?

A.-Little work seems to have been done with domestic pressure cookers, but, generally speaking, the effects may be expected to be similar to those of commercial canning. As compared with ordinary cooking, some further destruction of vitamin $B_{1}$ (thiamine) may occur, owing to the higher temperature reached. Loss of vitamin $\mathrm{C}$ may or may not be greater than with ordinary cooking, since, although the conditions are more drastic, the time of exposure is less. Meat and vegetable juice may be more abundant and should not be thrown away.

We have found no reference suggesting any danger of foodpoisoning resulting from the use of a pressure cooker. This idea may have arisen from the fact that meat cooked in this way may develop a bitter flavour. This has been ascribed to the partial breakdown of some of the proteins into simple peptides and amino-acids. On the other hand, the use of a pressure cooker in the home canning of vegetables obviates the risk of bacterial poisoning.

\section{Pruritus Senilis}

Q. -What is the best treatment for pruritus senilis and is a cure likely?

A.-There are many possible activating factors in senile pruritus, particularly emotional and nervous stresses and strains, metabolic disturbances, and deficiency states. Glycosuria. hypertension, arteriosclerosis and neoplasms must be carefully considered. In essential senile pruritus the senility of the skin itself may play some part, but the condition seems more often dependent upon arteriosclerotic changes affecting the central nervous system, and treatment is difficult. Local applications are not of much avail, though minimal doses of ultra-violet light or $x$ rays are sometimes of value. Stilboestrol 0.5 to $1 \mathrm{mg}$. combined with phenobarbitone gr. $1 / 2(32 \mathrm{mg}$.) occasionally helps.

\section{INCOME TAX}

All inquiries will receive an authoritative reply but only a selection can be published.

\section{Postgraduate Education for Ex-Service Medical Officers}

A note on this subject appeared in the Journal of Jan. 18 (p. 124). We have now been informed by the Ministry of Health that the Minister has been in communication with the Board of Inland Revenue regarding the liability for income tax of doctors holding posts or taking courses under the Posigraduate Scheme. He is advised that, as the practitioners holding Class I and Class III posts are employees of the hospitals to which they are appointed, the salaries of these posts and the allowances of $£ 100$ paid in lieu of board and lodging are assessable to income tax under Schedule E, and tax should be deducted by the employing hospital under the P.A.Y.E. provisions on making payments on account of these salaries and allowances.

The practitioners attending refresher courses provided under Class II will, in general, be liable to income tax under Schedule D upon the profits of their individual practices. Payments made to a practitioner in respect of subsistence, travelling expenses, and the cost of providing a locum, are not in themselves income liable to tax. If, however, a practitioner in arriving at the amount of his practice profits deducts the corresponding expenses incurred by him, then the payments received by way of reimbursement must be credited. For example, a doctor who uses his practice car to attend lectures and charges the full car expenses in his accounts should credit the amount received from the Ministry in respect of journeys to and from lectures. Similarly, if the cost of providing a locum is debited in the accounts the amount reimbursed by the Ministry should be credited.

\section{Letters and Notes}

\section{Bleeding Tooth-sockets}

Dr. J. F. MURPHY (Pickering, Yorks) writes: Troubles from a bleeding tooth-socket were ended for me by a method shown me by a neighbour dentist many years ago. It is extremely simple, painless, and instantly effective. One assumes of course that the gum is not so badly torn as to require a stitch. Two wool swabs of suitable size are prepared, one dry and one damp enough to coat itself thickly with crystals of permanganate of potash when dipped into the jar. The dry swab is pressed into the socket to check the bleeding as much as possible, and on withdrawal the swab coated with the crystals is pressed up into the socket and held there for about 30 seconds before withdrawal. A firm black adherent coagulum instantly forms and the bleeding is at an end. (No swab is left in.) Occasionally a further application of the crystals is required but not often. The coagulum disappears without trouble in the course of two or three days. For many years I have not known this method fail.

\section{Multihallucism}

Dr. Ronan O'RahiLly (Newcastle-upon-Tyne) writes: With reference to the photograph of Dr. Ardeshir K. Turner's case showing a Hindu with two big toes on each foot (March 29, p. 436), I should like to call attention to the skiagram (reproduced) which I possess through the kindness of Dr. T. Lodge, F.F.R. It shows a very rare condition of three big toes on one foot, making a total of seven digits on the right lower limb. The patient was a boy who was aged six months when the film was taken. The thickened first metatarsal can be seen to be associated with three biphalangeal digits. The remaining toes were normal. Other cases of pedal heptadactylism have been

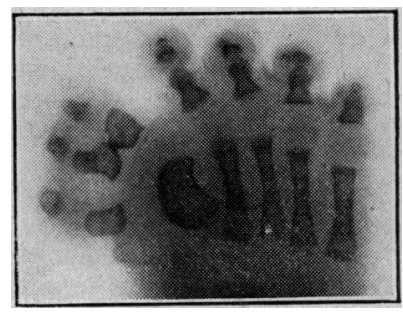

described (e.g., by Pires de Lima, J. A., Ann. Anat. Path. méd.-chir., $1933,10,1215$ ), and a case of octodactylism has been recorded by A. E. Sawday (British Medical Journal, 1928, 1, 846). Most instances of pedal polydactylism, however, are concerned with the lateral border of the foot, in contrast with the pre-axial distribution in the case illustrated here, as also in that of Dr. Turner.

\section{Chilblains}

Dr. Margaret Vivian (Bournemouth) writes: The woman doctor (March 1 issue) crippled with chilblains should try calciferol, and parathyroid and calcium tablets. I have cured my own by taking both these remedies together, when neither singly was completely successful.

\section{Treatment of Dipsomania}

Dr. H. Pullar-Strecker (Truro) writes: The reply (March 15, p. 365) and the references quoted refer to the American method, which is rather involved; emetine, not apomorphine, is their nauseating agent. The apomorphine method was evolved by J. Y. Dent, and is described in the issues of the British Journal of Inebriety from 1934 onwards.

\section{Correction}

A correspondent points out that the Cerebral Palsy Unit at Carshalton referred to in our annotation (April 5, p. 459) was founded by the cerebral palsy therapist 4 years ago. with the backing of the L.C.C.

All communications with regard to editorial business should be addressed to THE EDITOR, British MEDICal Journal, B.M.A. House. Tavistock SQUare, LONDON, W.C.1. TELEPHONE: EUSTON 2111. TELEGRAMS: Aitiology, Westcent, London. ORIGINAL ARTICLES AND LETTERS forwarded for publication are understood to be offered to the British Medical Journal alone unless the contrary be stated.

Authors desiring REPRINTS should communicate with the Publishing W.C.1 on receipt of proofs. TSS if reprints are required, as proofs Authors overseas shoulk

ADVERTISEMENTS should be addressed to the Advertisement Manager, B.M.A. House, Tavistock Square, London, W.C.1 (hours 9 a.m. to 5 p.m.) TELEPHONE: EUSTON 2111. TELEGRAMS: Britmedads, Westcent, London.

MEMBERS' SUBSCRIPTIONS should be sent to the SECRETARY of the TELERAMS : Medisecra, Westcent. Association.
London.

B.M.A. Scottish OfFICE: 7, Drumsheugh Gardens, Edinburgh 